\title{
Investigating the Factors Affecting Job Satisfaction and Turnover: Case of Sultan Qaboos University
}

\author{
Adel Ismail Al-Alawi ${ }^{1}$, Amal Suliaman Al-Azri ${ }^{2}$ and Hisham Naseem Mohammad ${ }^{3}$ \\ ${ }^{1}$ University of Bahrain, College of Business Administration, Department of Management and Marketing, \\ Kingdom of Bahrain \\ ${ }^{2}$ Sultan Qaboos University, Oman \\ ${ }^{3}$ Ministry of Education, Manama, Kingdom of Bahrain
}

Correspondence should be addressed to: Adel Ismail Al-Alawi; adel.alalawi@gmail.com

Received date: 2 July 2015; Accepted date: 7 January 2016; Published date: 22 August 2016

Academic Editor: Benish Chaudhry

Copyright @ 2016. Adel Ismail Al-Alawi, Amal Suliaman Al-Azri and Hisham Naseem Mohammad.

Distributed under Creative Commons CC-BY 4.0

\begin{abstract}
Job satisfaction has received wide attention as one of the core elements of an organization that is successful in achieving its purposes. This study aims to investigate the job satisfaction of Sultan Qaboos University (SQU) administrative staff by measuring the job satisfaction level of non-academic staff. The study is concerned with the problem of turnover amongst administrative employees in 2014 which was believed to be high by Majlis Al- Shura (Oman Parliament), this drove the university to create an incentive program through increasing salaries. This is a descriptive quantitative cross sectional applied research where data were collected by using a structured questionnaire consisting of 42 items covering seven domains of job satisfaction. The overall response rate (150 completed questionnaire) was 68\%, 137 (47.4\% males, $52.6 \%$ females) were usable. The outcome showed that administrative staffs were satisfied with their job. It also revealed that job satisfaction was affected by staff's gender, where males showed higher job satisfaction than females. It also showed that those who have shorter experience are more satisfied than those who have longer experience and those who hold lower qualifications and lower job levels have higher job satisfaction compared to those who have higher qualifications and job level.
\end{abstract}

Keywords: Factors affecting job satisfaction, Turnover, Qaboos University, Work motivation, Work quality, Workforce environment, working conditions, Incentive programs.

Cite this Article as: Adel Ismail Al-Alawi, Amal Suliaman Al-Azri and Hisham Naseem Mohammad (2016)," Investigating the Factors Affecting Job Satisfaction and Turnover: Case of Sultan Qaboos University", Journal of Human Resources Management Research, Vol. 2016 (2016), Article ID 301731, DOI: 10.5171/2016.301731 


\section{Introduction}

Job satisfaction has received wide attention as one of the core elements of an organization which is successful in achieving its purposes. The concept of job satisfaction was defined by some researchers such as Locke (1976, p1304) who defined it as "a pleasurable or positive emotional state resulting from the appraisal of one's job or job experiences", while Lofquist and Davis (1991, p27) defined it as "an individual's positive affective reaction of the target environment...as a result of the individual's appraisal of the extent to which his or her needs are fulfilled by the environment." It is also defined by Luthans (1994) as "an attitude developed by an individual towards the job and job conditions." Spector (1997) enhanced the definition as "an attitudinal variable that measures how a person feels about his or her job, including different facets of the job." According to these definitions, job satisfaction could be viewed as the status of how employees feel regarding their working environment.

Job satisfaction is a very important factor as it affects employees' working behavior, loyalty to the institution and their decisions about turnover (Clark 2001, Shields and Ward 2001). It also positively affects the employees' internal work motivation, work quality, performance, absenteeism and turnover (Bruce and Blackburn 1992; Fajana 2002). Nguyen et al, (2003) found that high levels of job satisfaction cause employees to be happier with their job environment, income, communication and workload and to be willing to act positively.

Therefore, the success of an institution in achieving its aims is directly linked to the satisfaction expressed by its employees (Freeman 2005). A study by Carpitella (2003) found that job satisfaction reduces turnover by $50 \%$ from the norms, increases customers' satisfaction to an average of $95 \%$ and lowers the cost of labor by $12 \%$. Harter et al (2002) found positive and substantive correlation between employees' level of satisfaction and the unit outcomes of productivity, profits, workplace accidents and customers' satisfaction.

To achieve the satisfaction of employees, the institution uses incentive programs to ensure the productivity, loyalty and low turnover rate of its employees (Toloposky, 2000). Alam et al,(2012, p35-36) suggested nine domains of job satisfaction which can be used to measure job satisfaction levels:"(1) Organization development; (2) Policies of compensation and benefits such as wage, salary reward and penalties; (3) Promotion and career development such as opportunity for promotion, equal opportunity, training programs; (4) Job satisfaction such as job design, responsibility, task identity, quantity of work; (5) Security which give employees assurance to keep their current job; (6) Working environment, such as feeling safe, comfortable, having a clean office, good services; (7) Relationship with supervisor; (8) Working group; (9) Leadership styles."(Küskü, 2003).

As job satisfaction has such an effect on the success of institutions, many researchers have conducted studies in different institutions; however, few of these studies have been concerned with higher education and particularly with administrative staff in universities. Küskü (2003) stressed the importance of evaluating the job satisfaction level of these employees because most research is mainly concentrated on profitmaking in industrial and service organizations and there is a growing interest in investigating job satisfaction of employees in higher education to achieve quality management. $\mathrm{He}$ also explained that the higher education institutions have intensive labor and their budgets depend on the effectiveness of their employees.

Several studies have been conducted about the job satisfaction of academics in higher education, yet few of them have been concerned with administrative staff in universities. These studies found high levels of job satisfaction (Olorunsola2010). Others 
found that employees are satisfied with university arrangements such as promotion and tenure process but not satisfied with their workload and salary (Leckie and Brett 1997). Some studies showed relationships between job satisfaction and work environment, salary, and relationships with colleagues (Küskü2003). Some studies found that job satisfaction correlates strongly with promotion (Ellickson and Logsdon 2002; Peterson et al 2003).

The effects of demographic variables on job satisfaction have been examined by some researchers. The results related to gender are varied; some showed that males had higher levels of job satisfaction (McIntyre and McIntyre 2010), while others showed that females' job satisfaction was higher than that of males (Smith 2009; Tulen and Serife 2012). While a research study by Al-Alawi and Al-Alawi (2014) in Bahrain stated that "Perceived levels of stress were statistically significantly associated with gender. Staff with moderate to high perceived levels of stress was more likely to be male compared to staff with low perceived levels of stress that were more likely to be female". Other studies showed no significant differences (Brown and Sargeant 2007). Some studies examined the effect of experience and found that those who have long experience tend to be less interested in institutions' turnover due to emotional attachment, which shows affective commitment and satisfaction (Mathieu and Zajac 1990; Meyer et al 2002).

The current study is concerned with examining the job satisfaction of Sultan Qaboos University's administrative staff. The basis of this study was the problem of turnover of administrative staff in the last few years, which drove the university to create an incentive program through increasing salaries in January 2014. However, Pfeffer, and Davis-Blake (1992), Ma, Samuels, and Alexander (2003), Trevor, Reilly and Gerhar (2012), Alam, Sameena, and Puja (2012) and Al-Alawi and Al-Alawi (2014) indicated that salary is not the only factor for turnover but that there are other factors. This study tries to investigate job satisfaction from different domains of job satisfaction to come up with a clear picture about the situation regarding job satisfaction at SQU.

The selection of SQU was based on the fact that it is the only governmental university in the Sultanate of Oman and government is highly involved with this university. The budget of the university has reached 140 million Omani Riyal in the year 2014 (1.00 Omani Riyal equals 2.60 US Dollars). The university is seeking success in obtaining international accreditation, so it is highly concerned about developing all facilities, services, work quality, products quality and achieving all that is required to satisfy the requirements.

This study aims to determine the level of job satisfaction of Sultan Qaboos University administrative staff and to identify the effect of some independent variables on the level of job satisfaction of University administrative staff. The study addressed two related research questions: (1) what is the level of job satisfaction of Sultan Qaboos University administrative staff? (2) What are the affecting job satisfaction factors of Sultan Qaboos University administrative staff according to their gender, experience, qualification and job level?

Hence, there is a lack of research studies in the field of higher education administrative staff in the Arab world, however, this study attempted to measure the job satisfaction and turnover of higher education nonacademic administrative staff in the Omani governmental university. Consequently, the significance of the study is to provide information about the level of job satisfaction of Sultan Qaboos University administrative staff and to provide an overview of the factors affecting the levels of job satisfaction and the possible reasons for the high turnover rate of staff. 


\section{Methodology}

In this section, participants, data collection, instrument and results are presented as follows:

\section{Participants}

The questionnaire was distributed randomly to 150 responses but only 137 (47.4\% males, $52.6 \%$ females) were usable and the remaining 13 questionnaires were not filled completely. Data were completed with a response rate of $68 \%$. These participants were selected randomly from those who agreed to participate and from those whom the researchers met in reception and meeting areas. Convenience sampling techniques were used in this research. This method involves acquiring participants in the place of work typically wherever they are available to participate. Descriptive Data Analysis in Table-1 shows there are more female participants in the study with response rate of $52.6 \%$ and the majority of responses have bachelor's degree (50.4\%). The table also illustrated that the majority (66.4\%) are only staff and it also indicated that a greater portion of participants (40.9\%) have 1 to 6 years of experience.

Table 1: Number \&Percentage of Variables

\begin{tabular}{|c|c|c|c|}
\hline Variables & & $\mathbf{N}$ & $\mathbf{\%}$ \\
\hline \multirow{4}{*}{ Gender } & Male & 65 & 47.4 \\
\cline { 2 - 4 } & Female & 72 & 52.6 \\
\cline { 2 - 4 } & Total & $\mathbf{1 3 7}$ & $\mathbf{1 0 0}$ \\
\hline \multirow{4}{*}{ Qualification } & Secondary & 8 & 5.8 \\
\cline { 2 - 4 } & Diploma & 39 & 28.5 \\
\cline { 2 - 4 } & BA & 69 & 50.4 \\
\cline { 2 - 4 } & MA & 21 & 15.3 \\
\hline & Total & $\mathbf{1 3 7}$ & $\mathbf{1 0 0}$ \\
\hline \multirow{4}{*}{ Job Level } & Manager & 9 & 6.6 \\
\cline { 2 - 4 } & $\begin{array}{c}\text { Manager's } \\
\text { assistant }\end{array}$ & 14 & 10.2 \\
\cline { 2 - 4 } & $\begin{array}{c}\text { Head of } \\
\text { Department }\end{array}$ & 23 & 16.8 \\
\cline { 2 - 4 } & Staff & 91 & 66.4 \\
\cline { 2 - 4 } & Total & $\mathbf{1 3 7}$ & $\mathbf{1 0 0}$ \\
\hline \multirow{4}{*}{ Experience } & 1 to 6 years & 56 & 40.9 \\
\cline { 2 - 4 } & 7 to 15 years & 38 & 27.7 \\
\cline { 2 - 4 } & Above 15 years & 43 & 31.4 \\
\cline { 2 - 4 } & Total & $\mathbf{1 3 7}$ & $\mathbf{1 0 0}$ \\
\hline
\end{tabular}

\section{Limited Number of Respondents}

Data were collected from only 137 out of 3220 administrative staff from Sultan Qaboos University. The current study had targeted to reach 500 respondents but due to the shortage of time it only acquired 200. Though, the returned amount was 150 as some of them were eliminated because they were incomplete.

\section{Instrument}

A questionnaire was used to gather data from the administrative staff. The questionnaire was developed by the researchers and was based on the previous studies such as Küskü (2003); Marvin (2006); Rita and Irena (2012). The questionnaire consisted of 42 items divided into seven domains. 
The questionnaire was validated by a group of judges from 2 human rescores managers, and 2 professors in Sultan Qaboos University and the 3 management professors from the University of Bahrain. The judges were asked to evaluate appropriateness of items to the purpose of the study, clarity items, as well as their correlation to each domain and formulation of every item. Based on the judges' comments and recommendations, the questionnaire was enhanced by modifying and rephrasing some items, and finally by adding new ones. The questionnaire reliability was obtained by piloting it to 20 staff and assessed by using Cronbach's Alpha test (.929).

\section{Results}

The analyses of the following research questions are below:

- What is the level of job satisfaction of Sultan Qaboos University administrative staff?

Table 2 shows the mean and standard deviations of the job satisfaction of Sultan Qaboos University administrative staff. Mean interpretation: 1-1.49 (very unsatisfied), 1.52.49 (unsatisfied), 2.5-3.49 (uncertain), 3.54.49 (satisfied), 4.5-5 (very satisfied).

Table 2: Means and standard Deviations of Staff Job Satisfaction

\begin{tabular}{|lccc|}
\hline \multicolumn{1}{|c}{ Satisfaction domains } & N & Mean & $\begin{array}{c}\text { Std. } \\
\text { Deviation }\end{array}$ \\
\hline Job Mission and evaluation system & 137 & 3.98 & 1.27 \\
\hline Work environment & 137 & 3.76 & 0.91 \\
\hline Satisfaction about working at SQU & 137 & 3.57 & 0.612 \\
\hline Salary Progression & 137 & 3.54 & 0.832 \\
\hline Office Services & 137 & 3.43 & 0.727 \\
\hline Administration system & 137 & 3.37 & 0.898 \\
\hline General Services & 137 & 3.17 & 0.91 \\
\hline Total & 137 & 3.55 & 0.612 \\
\hline
\end{tabular}

The result showed that SQU administrative staff were satisfied with their job and working at SQU. They were highly satisfied about job mission and evaluation systems, working environment and financial promotion but they were uncertain about general services and administration system.

Analyses of the questions relevant to the role of gender, experience, qualification and job are presented below:

\section{- The effect of Gender on Job Satisfaction:}

Table 3 indicates the mean and standard deviation values, independent samples and ttest analysis of variance of the responses given by the participants concerning their job satisfaction with respect to their gender. 
Table 3. Means, STD and t-test for the Gender

\begin{tabular}{|c|c|c|c|c|c|c|c|}
\hline Satisfaction domains & Gender & $\mathbf{N}$ & Mean & \begin{tabular}{|c|} 
Std. \\
Deviation \\
\end{tabular} & $\mathbf{t}$ & df & $\begin{array}{l}\text { Sig. (2- } \\
\text { tailed) }\end{array}$ \\
\hline \multirow[t]{2}{*}{ Administration system } & Male & 65 & 3.33 & 0.643 & \multirow[t]{2}{*}{0.43} & 135 & \multirow[t]{2}{*}{0.668} \\
\hline & Female & 72 & 3.4 & 1.082 & & 117.495 & \\
\hline \multirow{2}{*}{$\begin{array}{l}\text { Job Mission and evaluation } \\
\text { system }\end{array}$} & Male & 65 & 4.16 & 1.585 & \multirow[t]{2}{*}{1.617} & 135 & \multirow[t]{2}{*}{0.108} \\
\hline & Female & 72 & 3.81 & 0.9 & & 99.104 & \\
\hline \multirow{2}{*}{ Work environment } & Male & 65 & 3.98 & 0.928 & \multirow{2}{*}{2.728} & 135 & \multirow{2}{*}{.007 样 } \\
\hline & Female & 72 & 3.56 & 0.853 & & 130.453 & \\
\hline \multirow{2}{*}{ Office Services } & Male & 65 & 3.57 & 0.66 & \multirow{2}{*}{2.293} & 135 & \multirow{2}{*}{.023 * } \\
\hline & Female & 72 & 3.29 & 0.762 & & 134.768 & \\
\hline \multirow{2}{*}{ Financial promotion } & Male & 65 & 3.63 & 0.793 & \multirow{2}{*}{1.216} & 135 & \multirow{2}{*}{0.226} \\
\hline & Female & 72 & 3.46 & 0.863 & & 134.953 & \\
\hline \multirow{2}{*}{ General Services } & Male & 65 & 3.12 & 0.889 & \multirow{2}{*}{0.566} & 135 & \multirow{2}{*}{0.573} \\
\hline & Female & 72 & 3.21 & 0.933 & & 134.601 & \\
\hline \multirow{2}{*}{$\begin{array}{l}\text { Satisfaction about working } \\
\text { at SQU }\end{array}$} & Male & 65 & 3.63 & 0.557 & \multirow[t]{2}{*}{0.955} & 135 & \multirow[t]{2}{*}{0.341} \\
\hline & Female & 72 & 3.53 & 0.659 & & 134.422 & \\
\hline \multirow{2}{*}{ Total } & Male & 65 & 3.63 & 0.544 & \multirow{2}{*}{1.599} & 135 & \multirow{2}{*}{0.112} \\
\hline & Female & 72 & 3.47 & 0.662 & & 133.887 & \\
\hline
\end{tabular}

Significant Difference (a0.05).

The results showed that there are no significant differences due to the staff gender except in working environment and office services in favor of male staff. Males showed high level of job satisfaction compared to females.
- The effect of Experience on Job Satisfaction:

Table 4 indicates the results of ANOVA test of variance of the mean given by the participants concerning their job satisfaction with respect to their experience. 
Table 4: Results of ANOVA Test for the Staff experience

\begin{tabular}{|c|c|c|c|c|c|c|}
\hline \multicolumn{2}{|l|}{ Domains } & \begin{tabular}{|c|} 
Sum of \\
Squares
\end{tabular} & df & $\begin{array}{c}\text { Mean } \\
\text { Square }\end{array}$ & $\mathbf{F}$ & Sig. \\
\hline \multirow{3}{*}{$\begin{array}{l}\text { Administration } \\
\text { system }\end{array}$} & Between Groups & 7.821 & 2 & 3.91 & 5.134 & \multirow{3}{*}{.007 } \\
\hline & Within Groups & 102.067 & 134 & 0.762 & & \\
\hline & \begin{tabular}{|l|} 
Total \\
\end{tabular} & 109.888 & 136 & & & \\
\hline \multirow{3}{*}{$\begin{array}{l}\text { Job Mission and } \\
\text { evaluation system }\end{array}$} & Between Groups & 9.06 & 2 & 4.53 & 2.84 & \multirow{3}{*}{0.062} \\
\hline & Within Groups & \begin{tabular}{|l|}
213.712 \\
\end{tabular} & 134 & 1.595 & & \\
\hline & Total & 222.771 & 136 & & & \\
\hline \multirow{3}{*}{ Work environment } & Between Groups & 1.796 & 2 & 0.898 & 1.085 & \multirow{3}{*}{0.341} \\
\hline & Within Groups & 110.917 & 134 & 0.828 & & \\
\hline & Total & \begin{tabular}{|l|}
112.713 \\
\end{tabular} & 136 & & & \\
\hline \multirow{3}{*}{ Office Services } & Between Groups & 5.827 & 2 & 2.914 & 5.907 & \multirow{3}{*}{.003 } \\
\hline & Within Groups & 66.092 & 134 & 0.493 & & \\
\hline & Total & 71.92 & 136 & & & \\
\hline \multirow{3}{*}{ Financial promotion } & Between Groups & 1.787 & 2 & 0.894 & 1.294 & \multirow{3}{*}{0.278} \\
\hline & Within Groups & 92.519 & 134 & 0.69 & & \\
\hline & Total & 94.306 & 136 & & & \\
\hline \multirow{3}{*}{ General Services } & Between Groups & 7.957 & 2 & 3.979 & 5.084 & \multirow{3}{*}{.007 样 } \\
\hline & Within Groups & 104.863 & 134 & 0.783 & & \\
\hline & Total & 112.82 & 136 & & & \\
\hline \multirow{3}{*}{$\begin{array}{l}\text { Satisfaction about } \\
\text { working at SQU }\end{array}$} & Between Groups & 2.765 & 2 & 1.382 & 3.833 & \multirow{3}{*}{.024 拳 } \\
\hline & \begin{tabular}{|l} 
Within Groups \\
\end{tabular} & 48.329 & 134 & 0.361 & & \\
\hline & Total & 51.094 & 136 & & & \\
\hline \multirow{3}{*}{ Total } & Between Groups & 4.059 & 2 & 2.029 & 5.786 & \multirow{3}{*}{.004拳 } \\
\hline & Within Groups & 46.998 & 134 & 0.351 & & \\
\hline & Total & 51.057 & 136 & & & \\
\hline
\end{tabular}

* Significant Difference $(\alpha 0.05)$.

With respect to the experience variable, statistical differences were found in staff's level of job satisfaction in most domains except in job mission and evaluation systems and financial promotion which showed no difference. It revealed that those who have less experience ( 1 to 6 ) showed higher levels of job satisfaction compared with those who have more experience.

\section{- The effect of Qualification on the Job Satisfaction}

Table 5 indicates the results of ANOVA test of variance of the mean given by the participants concerning their job satisfaction with respect to their qualifications. There is a significant relationship ( $p<.05)$ between administrative staff qualification with general services. There is also a significant relationship between admin staff qualification (p>.05) with the level of satisfaction working in the SQU. The study shows that there is no significant relationship found with other domains such as administration system, job mission and evaluation system, work environment and office services. 
Table 5: Results of ANOVA Test for Staff Qualifications

\begin{tabular}{|c|c|c|c|c|c|c|}
\hline \multicolumn{2}{|c|}{ Domains } & \multirow{2}{*}{\begin{tabular}{|r|}
$\begin{array}{r}\text { Sum of } \\
\text { Squares }\end{array}$ \\
5.628 \\
\end{tabular}} & \multicolumn{2}{|c|}{ df $\begin{array}{c}\text { Mean } \\
\text { Square }\end{array}$} & \multirow{2}{*}{$\begin{array}{l}\mathbf{F} \\
2.393\end{array}$} & \multirow{3}{*}{$\begin{array}{l}\text { Sig. } \\
0.071\end{array}$} \\
\hline \multirow{3}{*}{$\begin{array}{l}\text { Administration } \\
\text { system }\end{array}$} & Between Groups & & 3 & 1.876 & & \\
\hline & Within Groups & 104.26 & 133 & 0.784 & & \\
\hline & Total & 109.888 & 136 & & & \multirow{4}{*}{0.064} \\
\hline \multirow{3}{*}{$\begin{array}{l}\text { Job Mission and } \\
\text { evaluation system }\end{array}$} & Between Groups & 11.78 & 3 & 3.927 & 2.475 & \\
\hline & Within Groups & 210.991 & 133 & 1.586 & & \\
\hline & Total & 222.771 & 136 & & & \\
\hline \multirow{3}{*}{$\begin{array}{l}\text { Work } \\
\text { environment }\end{array}$} & Between Groups & 2.241 & 3 & 0.747 & 0.899 & \multirow{3}{*}{0.443} \\
\hline & Within Groups & 110.472 & 133 & 0.831 & & \\
\hline & Total & 112713 & 136 & & & \\
\hline \multirow{3}{*}{ Office Services } & Between Groups & 2.478 & 3 & 0.826 & 1.582 & \multirow{3}{*}{0.197} \\
\hline & Within Groups & 69.442 & 133 & 0.522 & & \\
\hline & Total & 71.92 & 136 & & & \\
\hline \multirow{3}{*}{$\begin{array}{l}\text { Financial } \\
\text { promotion }\end{array}$} & Between Groups & 4.374 & 3 & 1.458 & 2.156 & \multirow{3}{*}{0.096} \\
\hline & Within Groups & 89.931 & 133 & 0.676 & & \\
\hline & Total & 94.306 & 136 & & & \\
\hline \multirow{3}{*}{ General Services } & Between Groups & 7.491 & 3 & 2.497 & 3.153 & \multirow{3}{*}{ 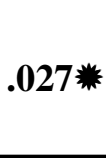 } \\
\hline & Within Groups & 105.33 & 133 & 0.792 & & \\
\hline & Total & 112.82 & 136 & & & \\
\hline \multirow{3}{*}{$\begin{array}{l}\text { Satisfaction abou } \\
\text { working at SQU }\end{array}$} & Between Groups & 3.931 & 3 & 1.31 & 3.695 & \multirow{3}{*}{.014 * } \\
\hline & Within Groups & 47.163 & 133 & 0.355 & & \\
\hline & Total & 51.094 & 136 & & & \\
\hline \multirow{3}{*}{ Total } & Between Groups & 3.711 & 3 & 1.237 & 3.474 & \multirow{3}{*}{.018 萧 } \\
\hline & Within Groups & 47.346 & 133 & 0.356 & & \\
\hline & Total & 51.057 & 136 & & & \\
\hline
\end{tabular}

*Significant Difference ( $\alpha 0.05)$. 
In respect of the qualification variable, statistical differences were found in general services, satisfaction about working at SQU. It revealed that those who have Secondary Diploma and BA were more satisfied than those who have an MA degree.

\section{The effect of job level on Job Satisfaction}

Table 6 indicates the results of ANOVA test of variance of the mean given by the participants concerning their job satisfaction with respect to their job level.

In respect of the job level variable, no statistical differences were found in staff job satisfaction in most of the domains except in general services which showed a difference. It revealed that managers, manager assistants and directors were less satisfied about general services when compared with ordinary staff. 


\begin{tabular}{|c|c|c|c|c|c|c|}
\hline \multicolumn{7}{|c|}{ Table 6. Results of ANOVA test for Staff Job Level } \\
\hline \multicolumn{2}{|c|}{ Domains } & \begin{tabular}{|l} 
Sum of \\
Squares
\end{tabular} & df & $\begin{array}{c}\text { Mean } \\
\text { Square }\end{array}$ & $\mathbf{F}$ & Sig. \\
\hline \multirow{3}{*}{$\begin{array}{l}\text { Administration } \\
\text { system }\end{array}$} & Between Groups & 3.347 & 3 & 1.116 & 1.393 & \multirow{3}{*}{0.248} \\
\hline & Within Groups & 106.541 & 133 & 0.801 & & \\
\hline & Total & 109.888 & 136 & & & \\
\hline \multirow{3}{*}{$\begin{array}{l}\text { Job Mission and } \\
\text { evaluation system }\end{array}$} & Between Groups & 7.507 & 3 & 2.502 & 1.546 & \multirow{3}{*}{0.206} \\
\hline & Within Groups & 215.264 & 133 & 1.619 & & \\
\hline & Total & 222.771 & 136 & & & \\
\hline \multirow{3}{*}{ Work environment } & Between Groups & 1.671 & 3 & 0.557 & 0.667 & \multirow{3}{*}{0.574} \\
\hline & Within Groups & 111.042 & 133 & 0.835 & & \\
\hline & Total & 112.713 & 136 & & & \\
\hline \multirow{3}{*}{ Office Services } & Between Groups & 0.156 & 3 & 0.052 & 0.096 & \multirow{3}{*}{0.962} \\
\hline & Within Groups & 71.764 & 133 & 0.54 & & \\
\hline & Total & 71.92 & 136 & & & \\
\hline \multirow{3}{*}{ Financial promotion } & Between Groups & 2.295 & 3 & 0.765 & 1.106 & \multirow{3}{*}{0.349} \\
\hline & Within Groups & 92.01 & 133 & 0.692 & & \\
\hline & Total & 94.306 & 136 & & & \\
\hline \multirow{3}{*}{ General Services } & Between Groups & 16.571 & 3 & 5.524 & 7.633 & \multirow{3}{*}{.000 拳 } \\
\hline & Within Groups & 96.249 & 133 & 0.724 & & \\
\hline & Total & 112.82 & 136 & & & \\
\hline \multirow{3}{*}{$\begin{array}{l}\text { Satisfaction about } \\
\text { working at SQU }\end{array}$} & Between Groups & 1.822 & 3 & 0.607 & 1.639 & \multirow{3}{*}{0.183} \\
\hline & Within Groups & 49.273 & 133 & 0.37 & & \\
\hline & Total & 51.094 & 136 & & & \\
\hline \multirow{3}{*}{ Total } & Between Groups & 2.06 & 3 & 0.687 & 1.864 & \multirow{3}{*}{0.139} \\
\hline & Within Groups & 48.997 & 133 & 0.368 & & \\
\hline & Total & 51.057 & 136 & & & \\
\hline
\end{tabular}

Significant Difference (a0.05). 


\section{Discussion}

The results of the study indicated that Sultan Qaboos University administrative staffs were satisfied with their job. This result could be due to the fact that the university is extremely concerned about providing a positive working environment to make its employees happier and more productive and about reducing turnover rates. It also could be because SQU is the only governmental university and it is highly supported by the government and under the eye of the government to maintain its quality and reputation as it carries the name of His Majesty. The university buildings and facilities have their effect on the levels of job satisfaction where the design of the university was well structured to provide a suitable working environment. Moreover, Yahy (2012) stated that it also could be due to the religious and cultural aspects which encourage the staff to be more positive in their work and to cooperate with others.

The satisfaction is a result of the university policies to maintain the quality of its products and services to compete with another private university which has become recently a competitor of SQU. It also is due to accelerated development in services such as new buildings which provide more offices, introducing new services for staff, and introducing all services electronically. It also is due to the service evaluation system which allows staff to evaluate the quality of all provided services through online questionnaires every year, which has led to the development of many of these services. The satisfaction is furthermore a result from the high increase in the staff salaries which took place in January 2014 and expectation of further increases in July 2014. The university policies were effective in raising the level of job satisfaction as literature showed a relationship between job satisfaction and work environment, salary, and relationships with colleagues (Küskü, 2003), and the correlation between job satisfaction and promotion (Ellickson and Logsdon 2002, Peterson, et al., 2003).
Based on the results, SQU, according to the literature, has achieved one of the main elements of an institution's success, which is employees' satisfaction (Freeman, 2005). Such levels of satisfaction for SQU are illustrated in Table 2. According to Clark (2001); Shields and Ward (2001) positively reflected on SQU staff's working behavior, loyalty and their interest in working instead. It will also lead to strengthening the relationships between staff, increasing cooperation, motivation and work quality and their performance (Bruce and Blackburn, 1992; Fajana 2002).

The results also showed that job satisfaction was affected by gender. The finding of this study supports the results of some previous studies which showed that males had higher levels of job satisfaction than females (McIntyre and McIntyre, 2010). This difference is mainly in working environment and office services which could be due to the fact that some females share offices with male staff, which may not be comfortable for them. It could also be because females feel greater pressure in relation to work, and they were less trusted by their leaders. They were also less trusted because of the speed of providing service.

In this research, respondents with lower job experience showed higher job satisfaction levels. This result contradicts with the literature which showed that those who have more experience have higher levels of job satisfaction (Mathieu and Zajac, 1990; Meyer et al., 2002). This result could be because those who have more experience have higher ambitions for getting better services were interested in developing administration systems. A study by Gesinde and Adejumo (2012) indicated that there was significant positive relationship between age and work experience and job satisfaction. Whereas, in a contradictory study by Hong, Hamid and Salleh (2013) indicated that age factor negatively affects the employee job satisfaction. The results may benefit organizations in enhancing overall job 
satisfaction and in empathizing organizational issues such as high turnover (Kerber and Campbell, 1987).

The result also revealed that administrative staff job satisfaction was affected by their qualification and job level. This result could be due to the high expectations of those who hold higher degrees and higher job level compared to those who hold lower degrees and lower job level. Such results could be due to comparisons in which these employees compare the services provided with other institutions which provide better services. It also could be due to the fact that the service provided is less than their expectations according to their qualification and working position.

\section{Study Limitations, Further research and Conclusion}

\section{Limitations}

The limitations of this study were as follow:

1. The data were limited to Sultanate Oman.

2. This research is limited to only one governmental university Sultan Qaboos University

3. Limited to non-academic staff - The research was collected solely from administrative employees of Sultan Qaboos University in Oman.

\section{Further Research}

Therefore, further study, in expanding the sample size of administration staff to be greater than the number who participated in this study is crucial in order to verify the generalizability of the findings to a larger population of Sultan Qaboos University. A more balanced ratio of men to women responses in this study could possibly provide more significant results to further understand perceived job satisfaction of males and females in relation to turnover and job satisfaction. Additionally, the study should also focus on comparisons between faculty members and administrative staff to measure the job satisfaction and turnover.

\section{Conclusion}

The study indicated that Sultan Qaboos University administrative employees were satisfied with their job and with working in a good workplace environment, which made the staff more productive and secure, and thus reducing the turnover rate. Furthermore, SQU believes that their staff is the number one asset, with the highest degrees of competence, integrity and professionalism. Although SQU instills in its people the principles of entrepreneurship and decision-making, the university needs to stress the positive aspects of job satisfaction and sort out the negative aspects which may affect staff job satisfaction currently or in the future. Furthermore, the Omani culture and the loyalty aspect inspire the workforce to be more confident in their job environment and to collaborate. Nevertheless, the job satisfaction may also result from the enhancement of the employees' salaries during the data collection time of this study.

\section{Acknowledgements}

The researchers thank all the staff who responded to their study's questionnaire and all the staff who helped them to distribute and gather questionnaires from different departments. They also appreciate the comments provided by Dr Nehal Elnaggar from Royal University for Woman in Bahrain and Dr Ebtisam Al-Alawi from Brunel University in the UK and Ms Sara Al-Bassam from Arabian Gulf University in Bahrain. 


\section{References}

1. Al-Alawi, A. I. and Al-Alawi, E. I. (2014). "Measuring Occupational Stress among Management Information Systems Workers and Users in the Financial Services Sector: The Case of Bahraini Bankers", International Journal of Scientific and Research Publications, 4(8) ISSN 2250-3153.

2. Alam, S., Sameena, R. and Puja, A. (2012). "Identification of Variables Affecting Employee Satisfaction and Their Impact on the Organization", IOSR Journal of Business and Management. 5(1) 32-39.

3. Brown, D. and Sargeant, M. (2007). "Job satisfaction, organizational commitment, and religious commitment of full time university employees",Journal of Research on Christian Education, 16, 211-241.

4. Bruce, W. M., and Blackburn, J. W. (1992) . Balancing job satisfaction and performance. Westport, CT: Quorum Books.

5. Carpitella, Bill. (2003). Make residential construction the industry of choice. Professional Builder, Oct 2003.

6. Clark, A.E. (2001). "What Really Matters in a Job? Hedonic Measurement Using Quit Data",Labour Economics, 8, 223-242.

7. Ellickson, M. and logsdon, K. (2002). "Determinants of Job satisfaction of municipal government employees", Public personnel management, 31(3), 343 - 358.

8. Fajana, S. (2002). Human Resource Management: An Introduction. Lagos: Labofin and Company.

9. Kusku, F. (2003). "Employee satisfaction in higher education: the case of academic and administrative staff in turkey", Career Development International, 8 (7), 347-356.

10. Freeman, S. (2005), "Employee satisfaction: The key to a successful company", [online], [Retrieved on March 15, 2016], http://library.lp.findlaw.com/articles/file/0 0301/008927/title/Subject/topic/Employm ent.

Gesinde, A. M., and Adejumo, G. O. (2012). "Effects of Age and Work Experience on Job Satisfaction of Primary School Teachers: Implications for Career Counseling". International Journal of Asian Social Science, 2(3), 302-309

11. Harter, J., Schmidt, F. L., and Hayes, T. (2002). "Business-unit level relationship between employee satisfaction, employee engagement, and business outcomes: A metaanalysis", Journal of Applied Psychology, 87, 268-279.

12. Hong, L. C., Hamid, N. I. N. A., and Salleh, N. M. (2013). "A study on the factors affecting job satisfaction amongst employees of a factory in Seremban, Malaysia". Business Management Dynamics, 3(1), 26-40.

13. Kerber, K. W., and Campbell, J. P. (1987). Job satisfaction: Identifying the important parts among computer sales and service personnel. Journal of Business and Psychology, 1(4), 337-352.

14. Leckie Gloria J. and Brett, Jim. (1997). Job satisfaction of Canadian University Librarians: A national survey. College and Research Libraries 58, January, 31-47.

15. Locke, E. A. (1976). The nature and causes of job satisfaction. In M. D. Dunnette (Ed.), Handbook of industrial and organizational psychology (pp. 1297-1349). Chicago: Rand McNally.

16. Lofquist, L. and Dawis, R. (1991). Essentials of person environment correspondence counselling, University of Minnesota Press. Minneapolis.

17. Lu, H., While, A. E., and Barriball, K. L. (2005). "Job satisfaction among nurses: A 
literature review", International Journal of Nursing Studies, 42, 211-227.

18. Luthans, F. (1994). Organizational Behavior. New York: McGraw-Hill.

19. Ma, C. C., Samuels, M. E., and Alexander, J. W. (2003). "Factors that influence nurses' job satisfaction". Journal of nursing Administration, 33(5), 293-299

20. Mathieu, J. E. and Zajac, D. M. (1990), "A review and meta-analysis of the antecedents, correlates, and consequences of organizational commitment", Psychological Bulletin, 108, 171-194.

21. Mclntyre, T. M., and Mclntyre, S. E. (2010). "Measuring job satisfaction in Portuguese health professionals: Correlates and validation of the job descriptive index and the job in general scale", International Journal of Selection and Assessment, 18, 425431.

22. Meyer, J. P., Stanley, D. J., Herscovitch, L. and Topolnytsky, L. (2002)."Affective, continuance, and normative commitment to the organization: A meta-analysis of antecedents, correlates, and consequences", Journal of Vocational Behaviour, 61, 20-52.

23. Nguyen, N., Taylor, J. and Bradley, S. (2003)."Relative pay and job satisfaction: some new evidence",Working paper 045, Department of Economics, Lancaster University Management School.

24. Olorunsola, E. (2010). "Job Satisfaction and gender factor of administrative staff in South West Niggria University", Contemporary Issue In Education Research, 3(10) 51 - 56.

25. Peterson, D. K., Puia, G. M and Sues, F. R. (2003). "YoTengo La Cainisela (I Have the Shint On)", "An Exploration of Job satisfaction and Commitment among Workers in thexico",Journal of Leadership and Organizational studies, 10(2), 73 - 88.

26. Rita, B and Irena, B. (2012). "Determinations of different group employees' job satisfaction: Litunia's University case", Human Resources Management and Ergonomics, I, 6 - 17.

27. Ryan, E. and Marvin, P. (2006). "Examining Herzberg's theory: improving job satisfaction among non-academic employees at a university", Research in Higher Education, 48 (2), 229 - 250.

28. Smith, P. C. and Stanton, J. M. (1999). "Perspectives of the measurement of job attitudes: The Longview", Human Resource Management Review, 8(4), 367-386.

29. Shields, M. A. and Ward, M. (2001). "Improving nurse retention in the National Health Service in England: The impact of job satisfaction on intention to quit", Journal of Health Economics, 20, 677-701.

30. Spector, P.E. (1997). Job Satisfaction: Application, Assessment, Causes and Consequences. Thousand Oaks, CA Sage.

31. Toloposky, A. (2000). What every supervisor should know. New York: McGrawHill.

32. Tulen, S. and Serife, Z. (2012). "Have gender differences in job satisfaction disappeared? A study of Turkish universities in North Cyprus, African", Journal of Business Management 6(1), 250-257.

33. Yahy, M. (2012). "Value of work in Islam and its contribution in sustainable development", International Symposium about sustainable development facilities in Islamic Economic, 3-4 December 2012 [online], [Retrieved June 12, 2014]. 
http://iefpedia.com/arab/wpcontent/uploads

34. Trevor, C. O., Reilly, G., and Gerhart, B. (2012). "Reconsidering pay dispersion's effect on the performance of interdependent work: Reconciling sorting and pay inequality". Academy of Management Journal, 55(3), 585-610.

35. Pfeffer, J., and Davis-Blake, A. (1992). "Salary dispersion, location in the salary distribution, and turnover among college administrators". Industrial and labor relations review, 45(4), 753-763. 